\title{
HYBRID NATURE OF EXTREMISM - COHESIVE CHARACTERISTICS OF ETHNO-NATIONALISM AND RELIGIOUS EXTREMISM AS GENERATORS OF BALKAN INSECURITY*
}

\author{
Milovan R. Subotić** and Miroslav Mitrovic ${ }^{* * * *}$ \\ University of Defense in Belgrade, Strategic Research Institute
}

\begin{abstract}
It will be no mistake to say that the region of the Balkans is the site with
'good soil' for conflicts. A significant number of scholars, who have analyzed the nature of conflicts in the Balkans, recognized the 1990s wars as religious conflicts. Others point out that the nature of these conflicts is based on ethnic and ethno-nationalist reasons. Taking into account the complex character of the „Balkans powder keg", it could be said that both views are correct. But then again, each of these conflicts had (and has) certain differences that support the thesis by which this particularly sensitive issue must by analyzed with exclusive respect for the role of religion. Namely, the role of religion is prominent and significant in almost all Balkan conflicts inspired by ethno-nationalist ideas and passions. In this regard, the main objective of this paper is to emphasize the socalled 'hybrid' character of the Balkans antagonisms and conflicts, which have extremist-religious and ethno-nationalist components at the same time.
\end{abstract}

Key Words: Balkans, violence, religious-funded extremism, ethnonationalism, hybrid conflict

"If they want peace, nations should avoid the pin-pricks that precede cannon shots". Napoleon Bonaparte

\section{Introduction}

ne of the most important characteristics of a man as a social being is identification with other people and collectivities. By identification with common symbolic entities, which impersonate nation and/or religion, the single individual (one person) provides the general framework of orientation in society. Furthermore, to acquire national

\footnotetext{
* This paper is a constituent part of the project „Hybrid Warfare-experience and perspectives" run by the Strategic Research Institute, University of Defense in Belgrade.

** Milovan R. Subotić, PhD, is a research associate in the Strategic Research Institute, University of Defense, Belgrade, milovan.subotic@mod.gov.rs

*** Miroslav Mitrović, PhD, is a research associate in the Strategic Research Institute, University of Defense, Belgrade, miroslav.mitrovic@mod.gov.rs
} 
Hybrid Nature of Extremism - Cohesive Characteristics of Ethno-Nationalism and ...

identity, a person has to identify himself/herself with nation, and that identification influences determination, as well as preservation of their national affiliation sense.

Nevertheless, consciousness of people about themselves, together with the created national identity, is still not nationalism. Only when "national consciousness grows into national ideology, then there is work with nationalism". ${ }^{1}$ The transition from man to ideologue, according to Šušnjić, is almost imperceptible. „Magnificent of own nation and its glorious past, leading to the contempt of all other peoples and their history, and there is no future and ideologies that could eradicate or suppress deeply ancient tribal instincts whose term nationalism“" ${ }^{2}$ highlights Šušnjić and continues: „about the small differences spread large clashes, preceded by organized hours of hate“. 3 Julien Benda, referring to nations as a particularly vulnerable and offensive organism, points out that "the nations have become susceptible as persons (mothers, fathers)“. 4

Thus, it is obvious that nationalism gains its meaning only in symbiosis with national (nationalistic) ideology. This relation is described in a symbolic and very humorous way by Fernando Fernández-Savater Martín in ", Three short reflections on nationalism and terrorism" when the analyses of 'isms' point out that they indicate "not obviously emphasizing something that is obvious, just like words ending with 'itis' indicate on inflammation, but not just that someone has some organ". In the same way, an individual can belong to the particular nation, and not to be a nationalist, the same as one "can have the bronchi, and that does not suffer from bronchitis".

In the same way, since national ideology crucially defines nationalism, ethnonationalist ideology has established a coordinated system of ethno-nationalists. Ethnonationalist ideology could be observed through its main features: ${ }^{7}$ simplification (of otherwise complex social reality), dichotomization (who is not with us is against us), rigidity (for ethno-nationalists it is interpreted as consistency, principle), demarcation (to know where is "ours", and where "theirs" starts from ), uniformity (uniformity enhances cohesion), degradation of rational (emotions ahead of nous), populism (populism thrives best in a society that is cohesive and uniform), anti-individualism (denial of individual right to diversity), moralism (moral is only that which supports group-national goals), traditionalism (containment and orientation to the past), longing for immortality (good deeds ethos settled as the way to eternal life-openly flirting with religion), biologism (the so-called „purity of ethnicity“, the cleanliness of nation, the increase of birth rate as a duty), extremism (radical demands accompanied by „now, all, rigid, fiercely“- the essential characteristics and, in a way, the content of many of the aforementioned physiognomies). ${ }^{8}$

\footnotetext{
${ }^{1}$ Đuro Šušnjić, Religija II, značenja, teorije, preplitanja, susreti, Čigoja štampa, Beograd, 2009, p.150.

${ }^{2}$ Ibid.

${ }^{3}$ The term „enduring hatred" can be considered a novelty in conflict analysis, which is interpreted by the fact that hatred is extremely intense and deliberate in public opinion of conflicting parties. Šušnjic quotes the example of Rome, which „concurred the Greek miracle in military but not spiritually: still remained deep respect for Greek culture“.

${ }^{4}$ Žilijen Benda (Julien Benda), Izdaja intelektualaca, Socijalna misao, Beograd, 1996. p. 25.

${ }^{5}$ Fernando Savater, „Tri kratka ogleda o nacionalizmu i terorizmu“ (203-208) in Mikel Asurmendi (ur.), Identitet i nasilje, XX vek, Beograd 2002, p. 207.

${ }^{6}$ Ibid.

${ }^{7}$ Classification of characteristics of ethno-national ideology (clarification of author), in: Nenad Kecmanović, Etnonacionalizam, Izabrana dela; 1-4; tom 2, Clio, Beograd, 2014, p. 118 - 133.

${ }^{8}$ lbid.
} 
It is important to note that certain features of ethno-nationalist ideologies are not identically (or with the same intensity) expressed in all ethno-nationalist movements. However, they are as a rule an example of preconceived attitudes and beliefs, largely monolithic and resistant to the possibility of any change.

Moreover, analyzing these characteristics that are specific 'doctrinal document' of the ideologues of ethno-nationalism, in many of them closeness with religious vocation could be notified. Indeed, if we put ethno-nationalism in the frame of the youngest monotheistic religion, it could be compared with the fundamentalist wing of Sunni Islam-Wahhabism.

Once established and strengthened at the level of minority communities, ethnonationalism became their most common instrument in an effort to achieve greater autonomy or independence, which broadly opened the door for ethno-nationalism to gain its own secessionist ${ }^{9}$-ethno-separatist form. Due to the fact that ethno-nationalism makes the essence of all secessionist movements, „Ethno-nationalist ideology is necessary to convince members of their target group that the state is not legitimate“. ${ }^{10}$ The dissolution of SFRY, with separations in successive and recursive manner, is the exact example of unified ethno-nationalism with elements of religious extremism in growing form of ethnoseparatism.

\section{Conflicting potential of ethno-nationalism}

The principle ciuis regio, eius natio ${ }^{11}$ in Eastern Europe was actually unknown in the $19^{\text {th }}$ century. The history of the $20^{\text {th }}$ century is chronicled with rapid moving and prosecution of ethnic groups, aimed at withdrawing aspiration to national borders by ethnicnational principles. According to Urs Altermatt, ethnic-nationalism has started from the utopia that a state should be adjusted to ethnicity/nation. ${ }^{12}$ This approach has brought much destruction in Europe during the $20^{\text {th }}$ century. In discussions on the theme of conflict in the modern world, Amartya Kumar Sen suggests that those conflicts are most frequently products of identity friction on the basis of ethnicity, religion, and culture, and that with appropriate incentives, tended awareness of identity within a group of people can be turned into a powerful weapon brutally treated by another. ${ }^{13}$ The high positioning of ethnicity and its interactive correlation of religion and culture has contributed to the fact that a significant number of scholars, who deal with the phenomenon of nationalism, em-

\footnotetext{
${ }^{9}$ According to James Crawford, secession creates a state through the use of force or by threat of force, without the consent of the former sovereign state. (James Crawford, The Creation of States in International Law, Second Edition, Oxford, Clarendon Press, 2006, p. 375). Julie Dahlitz suggests that secession could be recognized as the act when a substantial part of the population of a particular territory, which is a part of a state, expresses, by word or deed, the desire to become sovereign or to approach another sovereign state and become part of it (Julie Dahlitz, Secession and International Law, Conflict Avoidance; Regional Appraisals, The Hague, TMC Asser Press, 2003, p.6).

${ }^{10}$ Aleksandar Pavković, Petar Radan, Stvaranje novih država, teorija i praksa otcepljenja, Beograd, Službeni glasnik, 2008. p. 266.

${ }^{11}$ "Who owns land, owns nation, as well“.

${ }^{12}$ Urs Altermatt, Etnonacionalizam u Evropi, Svjetionik (trans. Gajo Sekulić), Sarajevo, 1997.p. 52.

${ }^{13}$ Amartya Kumar Sen, Identitet i nasilje - Iluzija sudbine, Masmedia, Grafički zavod Hrvatske, Zagreb, 2007, p. 15.
} 
Hybrid Nature of Extremism - Cohesive Characteristics of Ethno-Nationalism and ...

braces the thesis that ethnic nationalism has a lot of characteristics, which made it justifiably regarded as a kind of modern 'secular religion'. John Hutchison suggests that nations become something that we could call 'surrogate religion', ${ }^{14}$ and Anthony Smith ${ }^{15}$ emphasizes that nationalism is a logical extension of traditional religions. This thesis was supported earlier by Harold Lasswell's arguments. Namely, Lasswell thinks that ethnonationalism, as a secularized alternative to religious forms, is an ideal substitute for religion. ${ }^{16}$ Berdyaev also concluded that fanaticism has religious origins, and that it easily exceeds national and political sphere. ${ }^{17}$ The fact is that religious identity in pre-modern times was the basic form of collective identity, so the transfer to ethno-national identity is a logical starting point, primarily because it imposes itself as the new main mechanism of social integration, and disintegration, as well.

Namely, almost as much as it serves to collective cohesion, ethno-nationalism is also the cause and instrument of antagonisms among ethno-national communities. Segmentation into us and 'the others' is at the core of ethno-national concept. Dichotomization embodied in symbolic withdrawal and/or real border between us and 'them' is the essence of ethno-nationalist ideologies later embodied in acting operationalization of the ethno-nationalists. Speaking about the thematic characteristics of ethnonationalist ideology, Kecmanovic emphasizes the theme of: vulnerability, culprit of all, victims and sacrifices, right or crucial moment and finally, revenge and retribution. ${ }^{18}$ Indeed, if we try to implement this matrix given by Kecmanović on the ethno-national ideology of the Balkans societies, we could find remarkable matching with generators and motives of conflicts.

In general, violence is the main force behind emergence and change of ethnic or ethno-national identity, either in more common sense of helping a nation, or forcing people to change or disguise their identity, which is a rarity, and not an unusual phenomenon. Antagonisms, conflicts, and finally wars, have often been the engine of building a nation, and the Balkans are certainly not an exception. In short, the wars in the former Yugoslavia and the processes of national homogenization that followed them, were primarily motivated, as Duijzings ${ }^{19}$ suggested, by the need to create simple and unequivocal identities in the population, and to erase the elements of the mixture, 'pollution' and any kind of uncertainty that would endanger the newly created nation states. Therefore, it seems that violence in the creation of new states does not only result from conflicting and disparate identity, but, even more, it is mean for their creation.

\footnotetext{
${ }^{14}$ John Hutchinson, „Introduction: Global perspectives on religion, nationalism and politics“, in: R. Hefner, J. Hutchinson, S. Mels et. al. (edt.), Religions in Movement: The Local and the Global in Contemporary Faith Traditions, London, Routledge, 2013, p. 9.

${ }^{15}$ Anthony Smith, "Introduction: The formation of nationalist movements", u: A. D. Smith, Nationalist Movements, London, Macmillan, 1976, p. 19.

${ }^{16}$ Harold Lasswell, „World Politics and Personal Insecurity, New York, Whittlesey“, 1935, 50-51, in: Nenad Kecmanović, Etnonacionalizam, Izabrana dela; 1-4; tom 2, Clio, Beograd, 2014, p. 285.

${ }^{17}$ Nikolai Berdyaev (Николај Берђајев), „О франатизму, ортодоксији и истини“, Градина, Ниш, 1992. р. 69, in: Владета Јеротић, Вера и нација, Ars libri, Београд, 2004. p. 185.

${ }^{18}$ Nenad Kecmanović, Etnonacionalizam, Izabrana dela; 1-4; tom 2, Clio, Beograd, 2014, p. 134-143.

${ }^{19}$ Ger Dejzings, Religija i identitet na Kosovu, Biblioteka XXI vek, Beograd, 2005. p. 54.
} 


\section{Conflict Potential of Religious Extremism}

Since religion was endorsed on the throne of social reality, it represents the line of delimitation, or dividing line among identities of groups, and thus it has taken the significant place in contemporary national policies of great numbers of countries. Furthermore, national movements, which exist in the modern world, regularly have some religious tone, which could certainly become the source of extreme religious emotional state. Moreover, the nationalistic movements of the modern world, as a rule, follow a certain religious belief. "The reverse case, i.e. that extremist believers become nationalistsextremists, it is noticeably less precisely because they, by their unambiguous and inseparable ties, are already connected by a fanatic faith". ${ }^{20}$

Religious antagonism in the Balkans got its culmination, perhaps more than in other parts of Europe, during the Second World War. Liberalism, which has inherited the tradition of religious tolerance and separation of church and state (secularization), could never fully articulate or effectively convey its ideals in the Balkans. The supporters of communism, while declaring themselves unequivocally as atheists, saw in religions the means by which the ruling elites kept their population submissive and did not show the least sense for religious tolerance. „In meanwhile, the protagonists of the extreme right politics, saw their chance in fostering religious conflict which is undoubtedly due to the fertile ground, inevitably lead to the strengthening of clerical-fascist ideas in the Balkans". ${ }^{21}$

The end of the Second World War was labeled by the victory of the Communist movements in a large part of the Balkan Peninsula with the exception of Greece and Turkey. However, in most of the Balkans, ethnic and national identity has remained fixed and 'hugged' with religious one. Namely, Serbs, Bulgarians and Greeks were widely regarded as Orthodox, as well as Macedonians and Montenegrins (who passed through a characteristic process of national emancipation during this period), Slovenes and Croats as Catholics, and Turks, Bosniaks, as well as the majority of Albanians, were identified as Muslims. $^{22}$

This constellation resulted in the specifically difficult situation for individuals and minority groups, whose ethnic identity did not match the religious one, same as those who are in itself were merged several national and religious identities. However, the dominance of communist ideology emphasized that the atheistic character stood in the way of operational articulation of political intolerance. On the other hand, the fact is that the Communists have done almost nothing to have efficient and sustainable construction of a more tolerant society, trying to distance all religions from the public sphere and often used religious communities in order to maintain political and economic monopolies.

Thus, at the end of the 1980s, the SFR Yugoslavia became an atheistic or agnostic society to a great extent, but at the same time it was inhabited by ethnicities that built

\footnotetext{
20 Милован Суботић, Екстремизам под окриљем религије - исламистички екстремизам на примерима БиХ и Р. Србије, Медија центар Одбрана и Институт за стратегијска истраживања, Београд, 2015, p. 279.

${ }^{21}$ Ibid, p. 31.

${ }^{22}$ Vladimir Petrović, Politika i religija na Balkanu: Od pluralizma do homogenosti; od suživota do asimilacije, BOŠ, Centar za istraživanje religije, Beograd, 2013.
} 
Hybrid Nature of Extremism - Cohesive Characteristics of Ethno-Nationalism and ...

their identity with particularly strong support of religious affiliation with federal order and internal borders that were roughly crossed by ethnically mixed population. Therefore, the circumstances, which were reflected in the weakening of the state in the second half of the 1980s, the increase in tension between the elites of the federal units and the economic downturn of the country caused a rapid rise of nationalism, which was often manifested through the utilization of religious sentiments. The Serbian political elites identified their national interests with the space where there were numerous believers of the Serbian Orthodox Church, Croats forced the ideology of the defense of Catholicism, and the Bosniaks built their identity on the basis of belonging to the Islamic religious community. The policy of intolerance and untouchable ethnic and religious identities contributed to the outbreak of a civil war and the maintenance of confusion about its inevitability.

This peculiarity of the last war has led many theoreticians to the conclusion that the Balkans is trapped in religious and national intolerance. It went so far that the Balkans multi confessionals represented the inalienable cause of the conflicts that are the dominant characteristic of its past and which would inevitably be transferred to the future. However, religiously colored conflicts in the Balkans were the most commonly exploited religious differences by political factors and in the function of achieving the goals of the great powers, and the new national states, as well. ${ }^{23}$ The communities of believers and their leaders, in this way, have found themselves in the focus of conflicting political and economic interests. Many of them often took part in these struggles and contributed to intolerance, since religious dignitaries in the Balkans were often influential political and military leaders such as John of Capistrano in the $15^{\text {th }}$ century, Arsenije III Carnojević in the $17^{\text {th }}$ century, Bishop Petar II Petrović-Njegoš in the $19^{\text {th }}$ century, Anton Korošec and Momčilo Đujić in the $20^{\text {th }}$ century. ${ }^{24}$

However, there is no reason for conclusion of these conflicts' immutability in the religions of the Balkans and their assortment. In peacetime, in rare situations of political equilibrium, the Balkans peoples showed an enviable ability to overcome religious differences and build multi confessional communities. Even the strongest waves of violence failed to fully achieve the desired religious and ethnic homogeneity in the region, and when they partially succeeded, the price in human lives was extremely high.

Generally speaking, in discussions about religious extremism components we could easily fall into the deception that this form of violence steps out of the frame of political violence. However, taking into account the character of the commitment of extreme 'believers', we could notice the inextricable connection with almost all components of radical right extremism such as chauvinism, xenophobia, anti-liberalism, anti-Americanism, sexism and other similar ones. Furthermore, it seems that „this 'hybrid' extremism with elements of ethno and cleric-nationalism is, in fact, par excellence political extremism, which significantly influences the political identity and, consequently, the insecurity of the Balkan societies". ${ }^{25}$ However, Serbia is not spared these forms of political violence. ${ }^{26}$ The

\footnotetext{
${ }^{23}$ Милован Суботић, Екстремизам под окриљем религије - исламистички екстремизам на примерима БиХ и Р. Србије, Медија центар Одбрана и Институт за стратегијска истраживања, Београд, 2015, р. 32.

${ }^{24}$ Vladimir Petrović, lbid, 2013.

${ }^{25}$ Милован Суботић, „Екстремизам на мапи савремених асиметричних форми угрожавања безбедности“, у: Идентификовање савремених асиметричних форми угрожавања безбедности, (у штампи), Институт за стратегијска истраживања (р.1-60), Београд, 2017.
} 
extremist verbal commitment, and often overt violence implemented by right-wing extremist organizations and individuals in Serbia often try to justify their actions under vindication of 'holy' Orthodox reasons. In communication they use the well - known floccules: „For the honorable Cross and golden freedom!”, „With faith in God, freedom or death!" and others. ${ }^{27}$ Some of the church dignitaries do nothing to prevent such phenomenon. Furthermore, ,there is a great number of cases in which they often use speech and hyperbolas that in a civilized world could be recognized as language of hatred, and thus become a kind of spiritual movements for clerical-right extremist leaders and their followers". ${ }^{28}$ In their public performance with the characteristics of chauvinism, xenophobia, anti-liberalism, anti-Americanism, sexism, etc., which often cause outbreaks of open violence, the 'soldiers of extremism' in modern Serbia often declare that their 'mission' is in accordance with Orthodoxy (even more often in the use of 'sacred') and 'traditional values' of the Serbian people. Also, the dichotomy between umbrella institutions of believers, who practice the principles of the youngest monotheistic religion in Serbia („Islamic Community of Serbia“ and "Islamic community in Serbia“), as well as the actions of the radical Wahhabi movement, could be recognized as examples of extreme opportunities in the name of religion. ${ }^{29}$

\section{Hybrid character of the Balkan extremes}

Both religious and ethnic nationalism are used, among other things, for integration or more collective integration of people. The origin of the word religion (legare - bind, connect) indicates that one of the essential functions of religion is to connect people with a certain top-level supreme authority (God), and also to connect them to the community of believers. A great deal of the protective function of religion such as protection from natural disasters, enemies, feeling of isolation, evil fate, etc., comes first of all from beliefs that what happens to people is not accidental, or is not the result of what is called the case or bad luck. ${ }^{30}$ The feeling of belonging to a specific, clearly defined community such as the community of believers, and beliefs of people that belonging to certain religion directly means sharing the same fate of all those who are of the same faith, leads them to specific closeness, familiarity, thereby increasing their social integration.

Moreover, affiliation with certain ethno-national community connects people (mostly) with the same language, culture, beliefs, habits, myths, collective memories. As one of the basic forms of collective identity, ethno-national identity is at the same time one of the basic aspects of collective human integration. A unique power of the same by (ethno) national origin conditional collective integration of the people, is the fact that this form of

\footnotetext{
${ }^{26}$ The obvious connection of religious extremism with right - wing organizations indicates that religious extremism could be recognized as par excellence political question.

27 Милован Суботић, „Екстремистичке тенденције као препрека у (пре)обликовању политичког идентитета Србије“, Култура полиса бр. 21, Нови Сад, 2013, (163-181), р. 175.

${ }^{28} \mathrm{lbid}$.

${ }^{29}$ lbid.

${ }^{30}$ Dušan Kecmanović, Etnonacionalizam, Beograd, Clio 2014. p. 286.
} 
Hybrid Nature of Extremism - Cohesive Characteristics of Ethno-Nationalism and ...

association is strongly emotionally colored because in it like in all other communities of people who share the same faith-belief outweighs the knowledge, emotion over reason ${ }^{31}$.

People are not indifferent to failure or disadvantages affecting their (ethno) national community. The majority of people personally feel the burden of difficult times of their (ethno) national collective because they have been identified with this type of community as its constituent part. Moreover, integration in (ethno) national community is so strong that in good and bad times, collective and personal destiny is largely equalized. ${ }^{32}$ Historical experience shows that the latent tension between these two large different ethnonational groups could be easily transformed into an open antagonism and conflict. Furthermore, belonging to particular faith often includes different views of the world, lifestyle, habits, diet, and dress.

On the other hand, separation into us and 'the others' is in the center of the ethnonationalist concept and beyond ethno-nationalist view of the world. Dichotomization, the withdrawal of symbolic and realistic boundaries between us and 'them' is a very important part of every ethno-nationalist ideology and the practical action of ethno-nationalists. Symbiotic processes derive from the interaction of religions-ethnicity. They represent ethno-mobilization with pronounced religious narrative, „manipulation of the conceptual and symbolic universe of ethnic collectivity is the primary characteristic of the ethnonationalism and its protagonists and carriers are called ethno-nationalists“34.

Jonathan Fox in his work ${ }^{35}$ suggests how religion can cause a conflict among ethnicities or contribute to that conflict. 1) The religious view of the world is not just a definite interpretation of reality; it becomes an integral part of reality. Therefore, any kind of questioning such an indication of the world brings into question the world in which those who have adopted it live. This is often more than enough for conflict with those who have challenged us, our belief and our world. 2) The religious view of the world usually includes rules of behavior in very different circumstances and situations. The holy books consist of instructions on how to treat people of different faith and opponents of religion. It is said somewhere to be pursued with fire and sword. Such message, for example, is a requirement of keeping the Holy War. It is said somewhere to be tolerant of people of other religions, to respect their customs, culture, and way of life. However, it is difficult to find examples that some religious based nations which were waged war, but did not have any justification in the texts of the sacred books. ${ }^{36}$

Moreover, religion, besides the fact that it may mostly cause direct challenges and could accelerate the already existing conflicts, it could be an excuse for conflicts, which does not necessarily have anything to do with religious conviction. For example, religion could be pulled into a conflict by using its institutions to mobilize the population in order to achieve some political goals. Also, religion could be used as a source of legitimizing

\footnotetext{
31 lbid.

${ }^{32}$ Ibid.

${ }^{33}$ Dušan Kecmanović, 2014, p. 287.

${ }^{34}$ Silva Mežnarić, „Nacija i etnos u akciji: Etnonacionalizam i njegove paradigme“, Migracijske teme, Zagreb, 5/1989, (p. 113-121), p. 120.

${ }^{35}$ Jonathan Fox, Towards a Dynamic theory of Ethno - Religious Conflict, Journal of Nations and Nationalism 5 , 1999, p. 431-463.

${ }^{36}$ lbid.
} 
every condemnation of valid procedures. The legitimizing influence of religion is reflected, inter alia, in the fact that a killer becomes a martyr. They sacrifice life for faith and therefore deserve to be glorified in this world (special cemeteries, monuments, mentioning their name during religious and state festivities, notation in memories on won and lost battles). Finally, in the other, sacred world they could not miss rewards and enjoyment of every kind. $^{37}$

Religion and ethno-nationalism provide collective identity to people. The religious identity, which is older than the ethno-national identity, has been significant for ages, and it represents the fusion factor in crucial collective identity of an epoch. Nowadays, the ethnonational identity is the dominant aspect of the collective identity of people, regardless of whether the term 'national identity' refers to an identity that implies (and gives) belonging to a particular ethno-national collective. As it has already been pointed out, the first type of identity is an important aspect of the identity of a man, every human being, when it is within the boundaries of the national state to which it belongs and especially when it crosses them. The second kind of identity represents people as individuals belonging to a completely specific ethno-national cultural matrix and everything that it implies. ${ }^{38}$

In many cases the religious identity is an integral part of the ethno-national identity. These two identities are complemented and amplified; one implies the other, the other includes the first. This is more common in the environments in which the ethno-national concept prevails over the national concept of organizing social life, especially relations among people of different (ethnicity) nationality. Religious affiliation is especially powerful principle of distinguishing people of different ethno-national origin, when the other differences between them are small and unimportant. Also, „the religious factor has significantly contributed to the emergence of an ethno-nationalist movement in conditions where the minority population through religion differs from the dominant state culture/religion". ${ }^{39}$ The typical example of this statement is the ethno-nationalistic character of ethno-separatism in Kosovo and Metohija.

Finally, when religious and ethno-national affiliation coincide, as it is often the case, then the extremist matrix is manifested in a significantly enhanced and escalated division between us and 'them'. In this way the likelihood of antagonizing us and 'them' increases. The history of mankind is abundant with evidence of the accuracy of the last statement.

Within the scope of hybrid conflict concept, in which actual security agenda is widely recognized as 'Hybrid Warfare', ethno-nationalism and religious extremism have more than significant role in several aspects. Namely, in areas or regions of interest, ethicbased religious frozen conflicts or notoriously recognized religion divides and antagonisms are useful tools for achieving controlled influence on behalf of power that has organized and managed a conflict, in hybrid way of its execution. Conflict potentials of ethno-nationalism and religious extremism have been previously elaborated in this paper. However, the non-conventional usage of violence in the military or conflicts usage of it by Clausewitz' theory has not been done yet. Namely, if one side successfully achieves its strategic aim by usage of ethno-nationalism and religious extremism without open

\footnotetext{
${ }^{37}$ Dušan Kecmanović, 2014, p. 288.

${ }^{38} \mathrm{lbid}$.

${ }^{39}$ Urs Altermatt, Etnonacionalizam u Evropi, Svjetionik (trans. Gajo Sekulić), Sarajevo, 1997, p. 76.
} 
Hybrid Nature of Extremism - Cohesive Characteristics of Ethno-Nationalism and ...

declaration of war, then those two phenomena should be placed in the domain of hybrid security threats. Furthermore, considering contemporary analysis and critical observation of actual conflicts, we could conclude that hybrid warfare is not de facto conducted as the war in conventional understanding, and mostly as the concept of actual, geopolitical clash of interests. ${ }^{40}$ Hybrid warfare embodies the whole range of various models of conflicts, which are carried out with conventional and unconventional tactics and engaged forces including violence and civil unrest and criminal activity. ${ }^{41}$ If we consider conflict potentials of ethno-nationalism and religious extremism, their hybrid capabilities are more than obvious. Furthermore, hybrid warfare could be understood as a form of manifestation of strategic initiatives, which strive to accomplish aims by usage of possibilities observed according to the indicators of hybrid vulnerability as: dysfunctional state, the lack of state sovereignty, the existence of frozen conflicts, unresolved territorial disputes, the presence of arbitration or control of territory by supranational entities, ethnic and religious problems, separatism, extremism, unemployment, the existence of general poverty, longterm dissatisfaction of population with political and social solutions in leading a country, corruption, powerful criminal elements, institutions with separate centers of power and governance, etc. In the listed indicators, ethno-nationalism and religious extremism have significant contributing influence in the role of raising different forms of insecurity and hybrid security engagement. Moreover, if we locate ethno-nationalism and religious extremism through the scope of recognized pillars of acting forms of hybrid conflict concepts, ${ }^{42}$ instruments for their implementation are more than noticeable: propaganda, information abuse, public diplomacy misuse, creation of extremist hubs at the Internet social networks, proxy support of separatist movements, abuse of cultural and religious humanitarian work, etc.

\section{Conclusion}

Religion in the Balkans is a constituent element of the nation and nation state in a much greater extent than it is the case in Western Europe. The countries of Southeast Europe naturally understand themselves as cultural nations, in which the religious factor as an element of cohesion plays an important role. In the Balkans 'national religions' have much stronger connections and interactions with politics than in Western Europe. The reason for this could be found in the fact that throughout history church was the last resort of cultural freedom for the Balkan nations in long periods of political subjection. Namely, for the Balkan nations churches used to be guarantors of their ethnic and cultural identity through centuries. Perhaps the best illustration of this old 'hug' is the fact that the Balkan nations under Ottoman rule consisted of millets, which represented both the community of religion and the community of peoples. In essence, they did not have a special territory, and they were determined only by belonging to religion. In the Balkans,

\footnotetext{
${ }^{40}$ Timothy McCulloh, Richard Johnson, (2016), Hybrid Warfare, Tampa, JSOU.

${ }^{41}$ Miroslav Mitrović, (2017)."Hybrid Security Treats and Contemporary Approach to National Security", "Thematic Conference Proceedings of International Significance, International Conference "Archibald Reiss Days", The Academy of Criminal and Political Studies, Belgrade, Vol. 1, p. 325-334.

${ }^{42}$ Miroslav Mitrović, "Hibridno ratovanje i asimetrične bezbednosne pretnje", Beograd, Vojno delo, 5/2017.
} 
nations have lived together with each other. This uncertain situation has resulted in the fact that the intellectual elites of the Balkan nations have developed vision and aspirations, which are added the as much as possible areas in which lived members of the former millets. On the basis of this, the European powers used the knowledge about confronted ambitions and ethno-nationalist aspirations of local elites to meet their own needs and interests. Therefore, peace in the Balkans was possible only if some imperial force played the role of arbitrator between corrupt ethnics and religions, and thus established the semblance of an intercultural, inter-ethnic and inter-confessional order. After the Second World War, the communist ideology with a pronounced vocation of deethnonational and de-religious, was the rival community of religions, ethnicities and languages forced to such balance. The civil wars during the 1990s just reminded that they had not yet managed to move the still strong relapse of the territorial militia with quasistate autonomy to the western system of national states with solid territorial boundaries. The specific nationalism of the Balkan societies is basically ethno-nationalism, which is in a clear connection with the verse-funded extremism. In this way, the Balkans is colored with continuously strengthened extremist forces widely through the region. In general, religious identification has become less important than ethnicity because religious rivalry has been added to ethnic and ethno-national antagonisms.

In the context of understanding this phenomenon, it is very important to point out the ambivalent, and also the intensifying attitude of the political foundations of the so-called 'western' democracies. Namely, Western Europeans are inclined to observe the events in the Balkans, such as the Caucasus, as relics of anachronistic times and products of uncivilized variance. Europe, with its well-established forms of democratic values, should not be foreign to what is happening in the Balkans. „Problems induced in the so-called the weak states are incredible ease overwhelming to the region, and more and more thousands of miles of distant states considered to be countries of developed democracy“. ${ }^{43}$ Only intertwining of ethnic, religious, cultural and linguistic elements make the Balkans a paradigm, in which intra-European conflicts in language, ethnicity, religion, etc., meet and clash with each other in a pronounced and distorted form. In conclusion, religion and ethno-nationalism elaborated as hybrid phenomena at the core of potential extremism have significant potential for security and stability in general, especially in regions with complex history such as the Balkan one certainly is.

\section{References}

[1] Bauman, Zygmunt, Intimations of Postmodernity, Routledge, London, NewYork, 1992.

[2] Benda, Žilijen, Izdaja intelektualaca, Socijalna misao, Beograd, 1996.

[3] Crawford, James, The Creation of States in International Law, Second Edition, Oxford, Clarendon Press, 2006.

[4] Dahlitz, Julie, „Secession and International Law“, Conflict Avoidance; Regional Appraisals, The Hague, TMC Asser Press, 2003.

[5] Dejzings, Ger, Religija i identitet na Kosovu, Biblioteka XXI vek, Beograd, 2005.

\footnotetext{
${ }^{43}$ Милош Миленковић, Милован Суботић, „Насилни недржавни актери и позиција Србије“, Српска политичка мисао, Институт за политичке студије, 3/2017. (55-70), р. 57.
} 
Hybrid Nature of Extremism - Cohesive Characteristics of Ethno-Nationalism and ...

[6] Etnonacionalizam u Evropi, Svjetionik (prev. Gajo Sekulić), Sarajevo, 1997.

[7] Fox, Jonathan, „Toward a dynamic theory of ethno religious conflict“, Journal of Nations and Nationalism 5, 1999, 431-463.

[8] Hutchinson, John, "Introduction: Global perspectives on religion, nationalism and politics", u: R. Hefner, J. Hutchinson, S. Mels i drugi (ur.), Religions in Movement: The Local and the Global in Contemporary Faith Tradditions, London, Routledge, 2013.

[9] Kecmanović, Nenad, Etnonacionalizam, Izabrana dela; 1-4; tom 2, Clio, Beograd, 2014.

[10] Lasswel, Harold, World Politics and Personal Insecurity, New York, Whittlesey, 1935, 50-51, u: Kecmanović,Nenad, Etnonacionalizam, Izabrana dela; 1-4; tom 2, Clio, Beograd, 2014, стр. 285.

[11] Mežnarić, Silva, „Nacija i etnos u akciji: Etnonacionalizam i njegove paradigme“, Migracijske teme, Zagreb, 5/1989, (113-121), str. 120.

[12] Mitrović Miroslav, (2017)."Hybrid Security Treats and Contemporary approach to National Security", Thematic Conference Procidings of Interantional Significance, Interantional Conference "Arcihibald Reiss Days", Academy of Criminal and Political Studies, Belgrade, Vol.1, p. 325-334.

[13] Mitrović Miroslav, (2017). "Hibridno ratovanje i asimetrične bezbednosne pretnje", Beograd:Vojno delo, 5/2017.

[14] Pavković, Aleksandar, Radan, Petar, Stvaranje novih država, teorija i praksa otcepljenja, Službeni glasnik, Beograd, 2008.

[15] Petrović, Vladimir, Politika i religija na Balkanu: Od pluralizma do homogenosti; od suživota do asimilacije, BOŠ, Centar za istraživanje religije, Beograd, 2013.

[16] Savater, Fernando, „Tri kratka ogleda o nacionalizmu i terorizmu“ (203-208), u: Mikel Asurmendi (ur.), Identitet i nasilje, XX vek, Beograd 2002.

[17] Sen Kumar, Amartya, Identitet $i$ nasilje - Iluzija sudbine, Masmedia, Grafički zavod Hrvatske, Zagreb, 2007.

[18] Smith, Anthony, "Introduction: The formation of nationalist movements", u: A. D. Smith, Nationalist Movements, London, Macmillan, 1976, str. 19.

[19] Šušnjić, Đuro, Religija II, značenja, teorije, preplitanja, susreti, Čigoja štampa, Beograd, 2009.

[20] Timothy McCulloh, Richard Johnson, (2016), Hybrid Warfare, Tampa, JSOU.

[21] Берђајев, Николај, О франатизму, ортодоксији и истини, Градина, Ниш, 1992.

[22] Јеротић, Владета, Вера и нација, Ars libri, Београд, 2004.

[23] Миленковић, Милош, Суботић, Милован, „Насилни недржавни актери и позиција Србије“, Српска политичка мисао, Институт за политичке студије, 3/2017. (55-70), стр. 57.

[24] Суботић, Милован, Екстремизам на мапи савремених асиметричних форми угрожавања безбедности, у: Идентифриковање савремених асиметричних форми угрожавања безбедности, (у штампи), Институт за стратегијска истраживања (1-60), Београд, 2017.

[25] Суботић, Милован, „Екстремистичке тенденције као препрека у (пре)обликовању политичког идентитета Србије“, Култура полиса бр. 21, Нови Сад, 2013.

[26] Суботић, Милован, Екстремизам под окриљем религије - исламистички екстремизам на примерима БиХ и Р. Србије, Медија центар Одбрана и Институт за стратегијска истраживања, Београд, 2015. 